\title{
Dlouhodobá účinnost a bezpečnost kladribinu $v$ léčbě roztroušené sklerózy
}

\begin{abstract}
Jedna z přednášek věnovaných léčbě roztroušené sklerózy (RS) na 33. českém a slovenském neurologickém sjezdu, který proběhl na konci listopadu 2019 v Praze, byla zaměřena na dosavadní vědecké poznatky i praktické zkušenosti s perorálním kladribinem. Prof. Eva Kubala Havrdová doložila, že pulzní léčba perorálním kladribinem (podávaná v 1. a 2. terapeutickém roce) u pacientů s RS významně snižuje výskyt relapsů, zpomaluje progresi disability a potlačuje aktivitu choroby na magnetické rezonanci. Na základě dlouhodobých dat ukázala, že podíl pacientů s dosažením NEDA (stav bez klinické aktivity choroby) přetrvává i ve 3 . a 4. roce, kdy již není kladribin podáván. Nové poznatky doplnila o vlastní zkušenosti s kladribinem a potvrdila, že dlouhodobé sledování jeho bezpečnosti nenaznačuje žádná nová rizika.
\end{abstract}

\section{Podávání kladribinu}

Kladribin byl používaný pưvodně v injekční formě v léčbě vlasatobuněčné leukemie. V jiném perorálním dávkování $(3,5 \mathrm{mg} / \mathrm{kg}$ ) je nyní schválen k léčbě roztroušené sklerózy. Podává se ve dvou pulzech, kdy jeden pulz představuje užívání tablet v jedné denní dávce prvních 4-5 dnů dvou po sobě následujících měsíců. Druhý pulz se podává s odstupem jednoho roku po zahájení prvního pulzu. Ve 3. a 4. roce se léčebné pulzy nepodávají (SPC kladribin).

\section{Výsledky dvouleté studie CLARITY s kladribinem}

Účinnost perorálního kladribinu u pacientů s relabující-remitentní roztroušenou sklerózou (RRRS) byla hodnocena v porovnání s placebem ve dvouleté dvojitě zaslepené studii CLARITY (Giovanonni et al., 2011). Primárním sledovaným parametrem byl roční výskyt relapsů (ARR). Po 2. roce léčby bylo bez relapsu $80 \%$ pacientů s kladribinem (pokles relativního rizika v porovnání s placebem o 58\%,95\% Cl 0,33-0,52, $p<0,0001)$. Bez progrese disability potvrzené $s$ šestiměsíčním odstupem bylo po dbou letech při léčbě kladribinem $91 \%$ pacientů (pokles RR o $47 \%, 95 \% \mathrm{Cl} 0,36-0,79, \mathrm{p}=0,0016), 62 \% \mathrm{pa}-$ cientů nemělo žádné aktivní T2 léze na magnetické rezonanci (MR) a 87 \% bylo bez aktivních T2 lézí na MR. Konceptu NEDA-3 (bez aktivity choroby) zahrnujícího absenci všech těchto nálezů dosáhlo po dvou letech 47 \% pacientů ze skupiny s kladribinem v porovnání se 17,4\% pacientů s placebem. Post-hoc analýza této studie ukázala, že u pacientů s vysokou aktivitou RS ( $\geq 2$ relapsy během roku před vstupem do studie bez ohledu na předchozí užívání DMD nebo $\geq 1$ relaps $\vee$ predchozím roce $\mathrm{a} \geq 1 \mathrm{~T} 1 \mathrm{Gd}+$ léze Či $\geq 9$ T2 lézí při léčbě jiným DMD) znamenala léčba kladribinem sní̌ení relativního rizika ARR o 67 \% (95\% Cl 0,23-0,48) a relativního rizika šestiměsíční progrese disability o $82 \%(95 \% \mathrm{Cl}$ 0,07-0,43) (Giovanonni et al., 2019).

\section{Dlouhodobá účinnost} a bezpečnost kladribinu ve studii CLARITY EXTENSION

Dlouhodobé údaje o účinnosti a bezpečnosti kladribinu přineslo dvouleté prodloužení studie CLARITY - CLARITY EXTENSION,4,5 do které bylo zařazeno 867 z 1184 pacientů (73 \%), kteři dokončili základní studii. Pacienti, kteří v základní studii užívali placebo, byli v prodloužení studie léčeni kladribinem. Pacienti ze skupiny s kladribinem v základní studii byli v prodloužení randomizováni k podávání placeba nebo kladribinu. Primární sledované parametry zahrnovaly hlavně hodnocení bezpečnosti. Analýza účinnosti ukázala přetrvávající efekt kladribinu ve 3. a 4. roce sledování, kdy již léčba nebyla podávána. Po čtyřech letech od zahájení studie CLARITY bylo bez relapsu 71,2 \% pacientů původně léčených kladribinem, kteří v prodloužení dostávali placebo. Toto procento bylo srovnatelné se skupinou, která dostávala kladribin v základní studii i v prodloužení (obrázek 1) (Giovanonni et al., 2018). Rovněž podíl pacientů s NEDA-3 byl po čtyřech letech ve studii srovnatelný u pacientů léčených kladribinem jen první dva roky a po celé čtyři roky (Giovanonni et al., 2018). Výsledky také prokázaly dlouhodobou stabilizaci skóre disability (EDSS - Expanded Disability Status Scale). EDSS bylo u pacientů léčených kladribinem první dva roky studie stabilní po dobu pěti let od zahájení studie a progrese EDSS potvrzená s 3/6měsičním odstupem byla zaznamenána u méně než $30 \%$ takto léčených pacientů (Giovanonni et al., 2019). Pokud se týká bezpečnosti, podíl pacientů, kteří vysadili léčbu kladribinem, činil 3,5 \% v porovnání s 2,1 \% ve skupině s placebem. Studii CLARITY dokončilo 91,9 \% pacientů s kladribinem a 87 \% s placebem. Z nežádoucích príhod se významně častěji než u placeba vyskytovala lymfopenie (ve 21,6\% vs. 1,8\%). O lymfopenii 3. stupně (500-200 buněk na $\mathrm{mm}^{3}$ ) se jednalo jen ve $24,9 \%$ a o lymfopenii 4. stupně (<200 buněk/mm³) v 0,7 \% ().

Léčba RRRS perorálním kladribinem je podpořena více než 14 lety zkušeností v klinických studiích - CLARITY (Giovanonni et al., 20111; 
Obr. 1. Klinická účinnost perorálního kladribinu přetrvávala v prodloužení studie CLARITY až do 4. roku i bez podávání léčby ve 3. a 4. roce (Comi et al., 2018; Giovanonni et al., 2018)

Čas do prvního relapsu ve studiích CLARITY a CLARITY EXTENSION

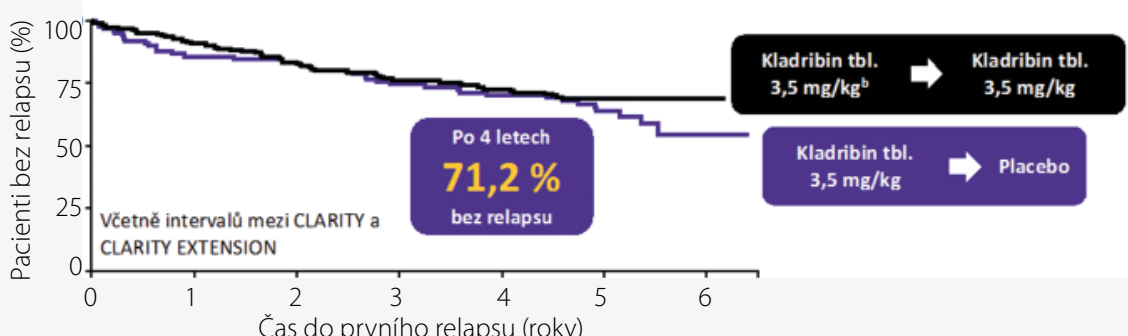

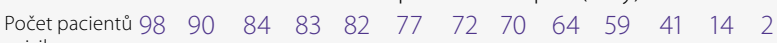

$\begin{array}{llllllllllllllll}\text { v riziku } & 186 & 177 & 169 & 163 & 154 & 148 & 141 & 136 & 126 & 109 & 72 & 38 & 4\end{array}$

Obr. 2. Riziko infekcív souhrnné bezpečnostní analýze pacientůs dávkou perorálního kladribinu 3,5 mg/ kg (Cook et al., 2019)

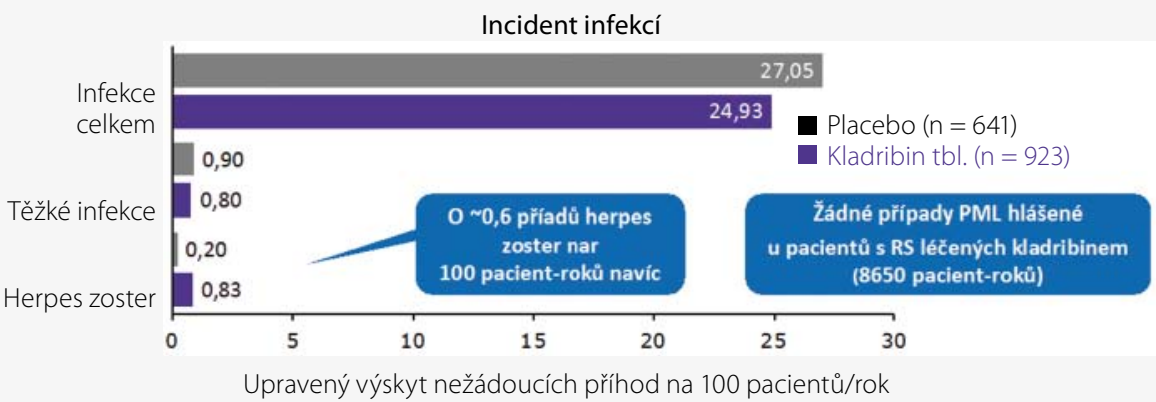

Comi et al., 2018), ONWARD (Montalban et al., 2018), ORACLE-MS (Leist et al., 2014) a v registru PREMIERE (PREMIER registry, 2019). Do programu klinických studií s perorálním kladribinem bylo zařazeno již přes 2000 pacientů a máme $k$ dispozici data z 10000 pacientoroků sledování (Cook et al., 2019). Souhrnná bezpečnostní analýza pacientů s dávkou kladribinu 3,5 mg/kg ukázala, že tato léčba v porovnání s placebem nezvyšuje výskyt celkových infekcí (24,93 případů na 100 pacient-roků v porovnání s 27,05 prípadů u placeba), a to ani těžkých infekcí (0,8 vs. 0,9 prípadu na 100 pacient-roků) (obrázek 2). Počet onemocnění herpes zoster byl při léčbě kladribinem v porovnání s placebem vyšší o 0,6 prrípadu na 100 pacientoroků. Nebyly hlášeny žádné prípady progresivní multifokální leukoencefalopatie (PML) (Cook et al., 2019). Výskyt malignit byl v porovnání s placebem u kladribinu vyšší, ale neobjevily se žádní hematologické malignity, kumulace nádorů určitého typu ani nárůst incidence v průběhu času (Cook et al., 2019). Dlouhodobé registry přinášejí

\section{LITERATURA}

1. Comi G, Cook S, Rammohan K, Soelberg Sorensen P, Vermersch P, Adeniji AK, Dangond F, Giovannoni G. Long-term effects of cladribine tablets on MRI activity outcomes in patients with relapsing-remitting multiple sclerosis: the CLARITY Extension study. Ther Adv Neurol Disord. 2018; 11: 1756285617753365. údaje o přetrvávající účinnosti a bezpečnosti léčby kladribinem s přiznivým poměrem prínosů a rizik. $\vee$ reálné praxi po registraci kladribinu nebyly u 8419 pacientů léčených kladribinem zaznamenány žádné nové bezpečnostní signály (Cook et al., 2019).

\section{Vlastní zkušenosti s kladribinem}

Od prosince 2018 zahájilo ve VFN léčbu kladribinem 48 pacientů s RRRS. Jedná se o 38 žen a 10 mužů průměrného věku 35,4 roku \pm 7,6 let. Z nežádoucích přihod se objevily běžné infekce, $1 \times$ černý kašel za měsíc po podání druhého pulzu. Někteří pacienti udávali asi měsíc trvající větší únavu. Lymfopenie se vyskytla u jednoho pacienta přechodně s hodnotou 500 buněk $/ \mathrm{mm}^{3}$ ve 2 . měsíci léčby s opětovným zvýšením počtu lymfocytů na $700 / \mathrm{mm}^{3}$ v 6 . měsíci. U pacientek s kladribinem je nutné bezpečné plánování těhotenství. S otěhotněním zatím nejsou v uvedeném souboru žádné zkušenosti.

\section{Kazuistika}

Žena, 40 let, dosud neléčená, byla v říjnu 2004 vyšetřena pro neuritidu optiku na levé straně. Zjištěny byly pozitivní vizuální evokované potenciály vlevo, v likvoru byly nalezeny oligoklonální pásy a MR mozku ukázala prítomnost vícečetných lézí včetně jedné charakteru tzv. černé díry. Tato první ataka RS nebyla léčena. V roce 2005 se u této ženy objevily parestezie v levé dolní končetině provázené mírnou parézou. Tato ataka byla přeléčena methylprednisonem a pacientka byla zařazena do právě probíhající studie CLARITY, do ramene $s$ kladribinem $3,5 \mathrm{mg} / \mathrm{kg}$. EDSS měla 0 . Ve 2. roce léčby se u ní objevila leukopenie 1 . stupně, nález se ale do konce terapeutického roku normalizoval. V roce 2008 vstoupila pacientka do prodloužení studie, kde byla randomizována do ramene s placebem. Během studie CLARITY EXTENSION se neobjevily žádné další relapsy, EDSS bylo nadále 0 a MR ukázalo několik drobných nových lézí. Další dlouhodobé sledování až do roku 2017 ukázalo absenci relapsů a dalších nežádoucích př́hod. Nálož lézí na MR činí 0,41 $\mathrm{cm}^{3}$ a frakce mozkového parenchymu 85,3\%.

\section{Závěr}

Kladribin je v České republice dostupný pro pacienty s relabující-remitentní RS (RRRS) od prosince 2018. Je podáván perorálně ve specifickém režimu pulzní léčby $v$ prvních dvou letech (2 pulzy s odstupem roku, kdy jeden pulz představuje dvě 4-5denní užívání s odstupem jednoho měsíce) bez dalšího podávání léčby ve třetím a čtvrtém roce. Léčba RRRS kladribinem významně snižuje ARR, zpomaluje progresi disability a omezuje aktivitu nemoci na MR. Bylo prokázáno, že klinický efekt přetrvává ve 3. a 4. roce bez dalšího podávání léčby. Souhrnná analýza údajů o bezpečnosti kladribinu potvrdila príznivý poměr mezi prínosem a riziky. Dlouhodobé sledování léčených pacientů i zkušenosti z praxe nenaznačují žádné nové bezpečnostní signály. Text tohoto článku nebyl recenzován. Pripravila MUDr. Zuzana Zafarová zafarova@seznam.cz Soběšinská 1908, 19016 Praha

2. Cook S, Giovannoni G, Leist T, Comi G, Syed S, Nolting A, Damian D, Schick R. Updated safety of cladribine tablets in the treatment of patients with multiple sclerosis: Integrated safety analysis and post-approval data. ECTRIMS Online Library. Sep 13, 2019; 278591; P1390.
3. Giovannoni G, Comi G, Rammoha K, Rieckmann P, Vermersch P, Dangond F, Keller B, Jack D. Long-term disease stability assessed by the expanded disability status scale in patients treated with Cladribine tablets in the CLARITY and CLARITY extension studies. ECTRIMS Online Library. 2019; 279715; EP1573. 
I INFORMACE - ZAZNĚLO NA SATELITNÍM SYMPOZIU SPOLEČNOSTI MERCK V RÁMCI 33. SJEZDU ČSNS

DLOUHODOBÁ ÚČINNOST A BEZPEČNOST KLADRIBINU V LÉČBĚ ROZTROUŠENÉSKLERÓZY

4. Giovannoni G, Cook S, Rammohan K, Rieckmann P, Sørensen PS, Vermersch P, Hamlett A, Viglietta V, Greenberg S. CLARITY study group. Sustained disease-activity-free status in patients with relapsing-remitting multiple sclerosis treated with cladribine tablets in the CLARITY study: a post-hoc and subgroup analysis. Lancet Neurol. 2011; 10(4): 329-337. 5. Giovannoni G, Keller B, Jack D. Durability of NEDA-3 status in patients with relapsing multiple sclerosis receiving cladribine tablets: CLARITY extension. ECTRIMS Online Library. 2018; 11: 228737; P894.

6. Giovannoni G, Soelberg Sorensen P, Cook S, Rammohan KW, Rieckmann P, Comi G, Dangond F, Hicking C, Vermersch P. Efficacy of Cladribine Tablets in high disease activi- ty subgroups of patients with relapsing multiple sclerosis: A post hoc analysis of the CLARITY study. Mult Scler. 2019; 25(6): 819-827.

7. Giovannoni G, Soelberg Sorensen P, Cook S, Rammohan K, Rieckmann P, Comi G, Dangond F, Adeniji AK, Vermersch P. Safety and efficacy of cladribine tablets in patients with relapsing-remitting multiple sclerosis: Results from the randomized extension trial of the CLARITY study. Mult Scler. 2018; 24(12): 1594-1604. 8. Leist TP, Comi G, Cree BA, Coyle PK, Freedman MS, Hartung HP, Vermersch P, Casset-Semanaz F, Scaramozza M; oral cladribine for early MS (ORACLE MS) Study Group. Effect of oral cladribine on time to conversion to clinically definite multiple sclerosis in patients with a first demyelinating event (ORACLE MS): a phase 3 randomised trial. Lancet Neurol. 2014; 13(3): 257-267.

9. Montalban X, Leist TP, Cohen BA, Moses H, Campbell J, Hicking $C$, Dangond F. Cladribine tablets added to IFN- $\beta$ in active relapsing MS: The ONWARD study. Neurol Neuroimmunol Neuroinflamm. 2018; 5(5): e477.

10. PREMIERE registry. https://clinicaltrials.gov/ct2/show/ NCT0101335025. Cook S, Leist T, Comi G, Montalban X, Giovannoni G, Nolting A, Hicking C, Galazka A, Sylvester E. Safety of cladribine tablets in the treatment of patients with multiple sclerosis: An integrated analysis. Mult Scler Relat Disord. 2019; 29: 157-167.26.

11. SPC kladribin. www.sukl.cz. 